\title{
The Character of The Students in MTs. Al-Mahalli Bantul Yogyakarta (A Comparative Study on Students Staying in Pesantren and Outside Pesantren)
}

\author{
Riska Anintyawati \\ Nahdlatul Ulama University - Yogyakarta, Indonesia \\ Anintyawati@gmail.com
}

DOI: https://doi.org/10.21154/ sajiem.v2i1.39

\begin{abstract}
This research aims to reveal: The comparison of character between students living in pesantren and those living outside pesantren in MTs. Al-Mahalli Bantul, Yogyakarta. This research is a comparative study with the quantitative approach. The population is 276 students of MTs. AlMahalli Bantul, Yogyakarta. The research sample was the population. The data on character were collected using questionnaire. The validity testing was conducted by expert judgement and exploratory factor analysis (EFA). The reliability was assessed by Cronbach's Alpha formula. The data analysis techniques included the descriptive technique, tests of prerequisites analysis, i.e. tests of normality and homogeneity. The hypothesis testing used the independent sample T-test at the significance level of 0,05 . The results are as follows. There are several character differences between students living in pesantren and those living outside pesantren, the result of hypothesis testing shows that the null hypothesis (Ho) is rejected and the alternative Hypothesis ( $\mathrm{Ha})$ is accepted (t-arithmetic $>\mathrm{t}$ table $(7,823>1,971)$. There are differences in the average value at each new character between the two groups of students. The religious character value of the students living in pesantren is 3.388, while those living outside pesantren is 3,139. The honest character value of the students living in pesantren is 3,071, while those living outside pesantren is 2,844 . The tolerance character value of the students living in pesantren is 3,277, while those living outside pesantren is 3,116. The discipline character value of the students living in pesantren is 3,050, while those living outside pesantren is 2,766 . The independent character value of the students living in pesantren is 2,815 , while those living outside pesantren is 2,504 . The responsible character value of the students living in pesantren is 2,740 , while those living outside pesantren is 2,618 .
\end{abstract}

Keywords: character; pesantren 


\section{Introduction}

Today, in making good characters in students is a big challenge especially in the era of globalization, where the advancement of technology and information plays an active role in the moral degradation of this nation. Based on the research on Performance Values: The Do Can Foster Their Development, written by Character Education Partnership (CEP), states that education has two great goals, namely to help students become smart and to help students be good. ${ }^{1}$ However, the still low discipline and honesty of the young generation now also need to be considered because it is closely related to the formation of student characters. Based on the results of research conducted by Munawaroh on "Behavior of Discipline and Honesty of Young Generation in Yogyakarta Special Region" shows that the discipline and honesty of young generation of DIY is still low. This should not be continuously ignored and must be addressed, especially starting with through educational institutions as a forum or place for the ongoing process of education along with the process of culture. ${ }^{2}$ The educational institutions referred to in this study include pesantren-based schools where there are students living in pesantren and there are students living outside the boarding school. Because the student residence here functions as an external factor affecting the character of the student.

In this study the researchers linkedstudent residences, namely students who live in the pesantren and outside the pesantrentowards the character of students. Based on research conducted by Restianingsih(2016) on "Character of Students Living in Islamic Boarding Schools (Mukim) and inHouse (Laju) in the Social Studies Learning Process at Diponegoro Junior High School, Depok, Sleman Regency". The results showed that the students of SMP Diponegoro,whether they live in the pesantren (mukim) or at home (rate), there is a differencethe average character score between the two groups of students, especially on characterdisciplined, honest, and independent even though the difference is not very high.Based on this research, it can be seen that there are differences in characterbetween students who live in the pesantren (mukim) and at home (rate) onsocial studies learning so that this research becomes relevant research forresearchers to conduct research on the differences in character between students who arelive in the pesantren and outside the pesantren on social studies learning. ${ }^{1}$

The difference between this study and Restianingsih's (2016) research isIn this study, researchers added to the variable of achievement and research placedone at MTs. Al-Mahalli Bantul Yogyakarta. Madrasah Tsanawiyah (MTs)is one of the educational institutions that is specialized as a schoolcurriculum there are lessons about Islam. This researchdone at MTs. AlMahalli Bantul Yogyakarta because when viewed from the sideresidence at MTs. Al-Mahalli can be grouped into two, namely studentswho live in the pesantren and outside the pesantren (live with their parents).

Character building in MTs students. Al-Mahalli in part greatly influenced by the culture of the pesantren. But this is not the case at all MTs students. Al-Mahalli, because there are students who do not live in the pesantren. By therefore, the environment where students live will also influence formation of student character. Based on the background above, then the researcher is interested in researching further about the problem through a study by title "The Character of The Students in MTs. Al-Mahalli Bantul Yogyakarta (A Comparative Study on Students Staying in Pesantren and Outside Pesantren)".

\footnotetext{
${ }^{1}$ Restianingsih, P., "Karakter Siswa yang Tinggal di Pesantren (Mukim) dan di Rumah (Laju) pada Proses Pembelajaran IPS di SMP Diponegoro Depok, Kabupaten Sleman,” : Pascasarjana UNY, 2016.

${ }^{2}$ Munawaroh, S. Perilaku disiplin dan kejujuran generasi muda di Daerah Istimewa Yogyakarta. Yogyakarta: Balai Pelestarian Nilai Budaya, 2013.
} 
a. Character

Kamaruddin reveals about the definition of the character ie."The character is values of universal human behavior that covers all human activities, both in order to relate with God, with himself, with others, as well as with the environment, which manifests itself in the mind, attitudes, feelings, words, and actions based on religious norms, laws, manners, culture, and customs". ${ }^{3}$

Lickona also provides a complete definition of the character. Lickona mentions that the character is "a reliable inner disposition to respond to situations in a morally good way. Character so conceived has three interrelated parts: moral knowing, moral feeling, and moral behavior". ${ }^{4}$ Dammon defines that "charachter as an individual's set psychological characteristics that affect that person's ability and inclination to function morally. ${ }^{5}$ Character is comprised of those characteristics that lead a person to do right thing or not to do right thing". Conclusion, character is the character or personality of a person, affecting the behavior and mindset of a person, a person can be said to character if his behavior in accordance with ethics and moral rules.

The expected character values can be formed within the students. A study from The Joseph Institute of Ethics in Kamaruddin mentions that there are six types of characters are as follows.

“a) Trustworthiness, the shape of the character that makes a person: integrity, honesty, and loyalty. b) Fairness, shape the character that makes a person have an open mind and do not like to take advantage of others. c) Caring, the shape of the character that makes a person have a caring attitude and concern for others and the social conditions of the neighborhood. $d$ ) Respect, the shape of the character that makes a person always appreciate and respect others. e) Citizenship, the shape of the character that makes a person aware of the laws and regulations as well as care for the natural environment. f) Responsibility, the form of the character that makes a person responsible, disciplined, and always do things as good as possible".

However, the character possessed by a person will differ from one individual to another. Character that is formed in a person depends on how one manages and develops the basic character that is in each individual. Indonesia Heritage Foundation (IHF) in Andrianto, has compiled a series of values that should be taught to children, which then summarized into nine pillars of character are: ${ }^{6}$

1) The loving character of God the Almighty and all of His creation

2) Independence and responsibility

3) Honesty / trust and wisdom

4) Respect and courtesy

5) Generous, helpful and gotong royong

6) Confident, creative, and hardworking

7) Leadership and justice

8) Good and humble

9) Tolerance, peace and unity

Based on the character values described above, in order to avoid overlapping and causing confusion for the students, the researcher concludes choosing six character values, because it

${ }^{3}$ Kamaruddin, S. A., "Character Education and Students Social Behavior". Journal of Education and Learning 6 (4), 223-230 (2012).

${ }^{4}$ Lickona, T.,"Educating for character: How our school can teach respect and responsibility," Bantam books, 1991.

5 Damon, William, Bringing in a New Era in Character Education. California: Hoover Institution Press. 2002

${ }^{6}$ Andrianto, T. T., “Mengembangkan Karakter Sukses Anak di Era Cyber,” Ar-Ruzz Media, 2011. 
is adapted to characters that reflect the values of characters that can be formed in the boarding school and can reflect the character good for a student. The six character values will be used as a guide for researchers to create indicators on research instruments. The values of these characters are religious, honest, disciplined, independent, responsible, and tolerant.

b. Pesantren

Pesantren is the first model of Islamic education in Indonesia that still exist until now. Rohmaniyah \& Woodward reveals that pesantren education is more than just the transmission of knowledge, because it aims to instill religious values as the basis of a type to build and maintain community morale both based on the bonds of students, teachers and the sharing of religious knowledge gained through pesantren. ${ }^{7}$ Pesantren as the oldest educational institution in Indonesia, has several characteristics that distinguish with other educational institutions. According to Dhofier pesantren has five basic elements, namely: mosques, kiai, santri, pondok, and teaching of classical Islamic books. These five elements are characteristic of pesantren. ${ }^{8}$

\section{Research Method}

This study uses a type of comparative research with a quantitative approach. according to Sugiyono states that comparative research is a study comparing the existence of one or more variables in two or different samples, at different times. ${ }^{9}{ }^{9}$. this study uses comparative research because it is appropriate to aim to find differences in learning achievement and character between students living in pesantren and outside pesantren in IPS learning in MTs. Al-Mahalli Bantul Yogyakarta. The data collected from the results of this study will be analyzed with the help of Statistical Product and Service Solutions (SPSS) program version 22.0.

Data collection techniques used in this study are questionnaires. Questionnaire in this research is used to measure student character variable. The validity testing was conducted by expert judgement and exploratory factor analysis (EFA). The reliability was assessed by the Cronbach's Alpha. The data analysis techniques included the descriptive technique, tests of analysis prerequisites, i.e. tests of normality and homogeneity. The hypothesis was using Independent T-test.

\section{Findings and Discussion}

Table 1 . The religious character value of the students living in pesantren and living outside pesantren

\begin{tabular}{|c|c|c|c|c|c|c|}
\hline & \multirow[b]{2}{*}{ Statistics } & \multicolumn{4}{|c|}{ Religious } & \multirow[b]{2}{*}{ Total } \\
\hline & & Very low & Low & High & $\begin{array}{l}\text { Very } \\
\text { High }\end{array}$ & \\
\hline \multirow{3}{*}{$\begin{array}{l}\text { living in } \\
\text { pesantren }\end{array}$} & Count & $\mathrm{O}$ & 3 & 40 & 82 & 125 \\
\hline & $\begin{array}{l}\text { \% within Tempat } \\
\text { Tinggal }\end{array}$ & .00 & 2.40 & 32.00 & 65.60 & 100.00 \\
\hline & $\%$ of Total & .00 & 1.09 & 14.49 & 29.71 & 45.29 \\
\hline \multirow{3}{*}{$\begin{array}{l}\text { living outside } \\
\text { pesantren }\end{array}$} & Count & 1 & 13 & 70 & 67 & 151 \\
\hline & $\begin{array}{l}\text { \% within Tempat } \\
\text { Tinggal }\end{array}$ & .66 & 8.61 & 46.36 & $44 \cdot 37$ & 100.00 \\
\hline & $\%$ of Total & .36 & 4.71 & $25 \cdot 36$ & 24.28 & $54 \cdot 71$ \\
\hline
\end{tabular}

${ }^{7}$ Rohmaniyah, I., \& Woodward, M., "Wahhabism, Identity and Secular Ritual: Graduation at an Indonesian High School”. Jurnal Al-Jami'ah, 50 (1), (2012).

${ }^{8}$ Dhofier, Z., "Tradisi Pesantren Studi Tentang Pandangan Hidup Kiai," LP3ES, 2011.

${ }^{9}$ Sugiyono., "Metode Penelitian Kuantitatif Kualitatif dan R\&D," Alfabeta, 2015 


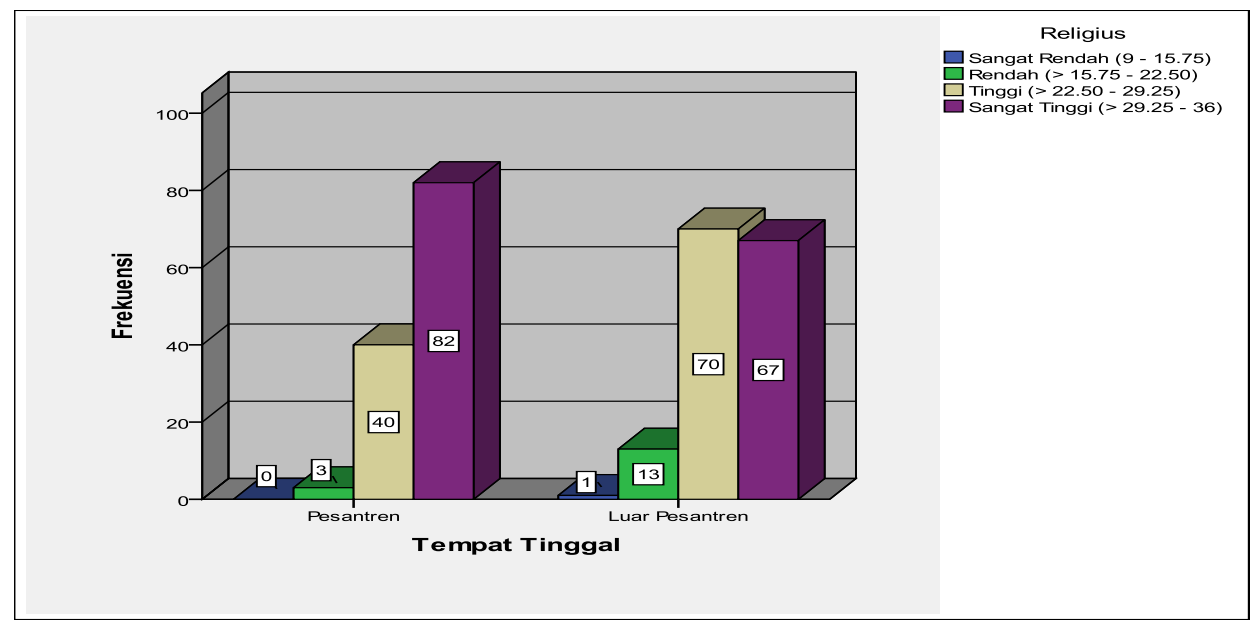

Figure 1. Differences The religious character value of the students living in pesantren and living outside pesantren

Table 2. The honest character value of the students living in pesantren and living outside pesantren

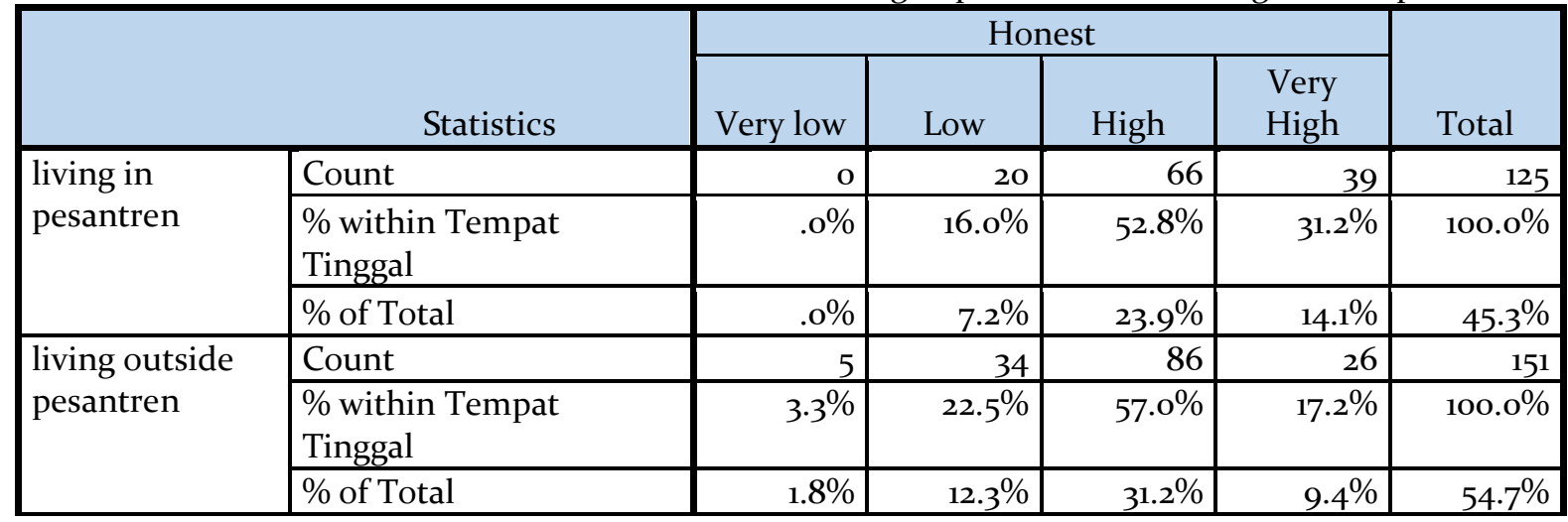

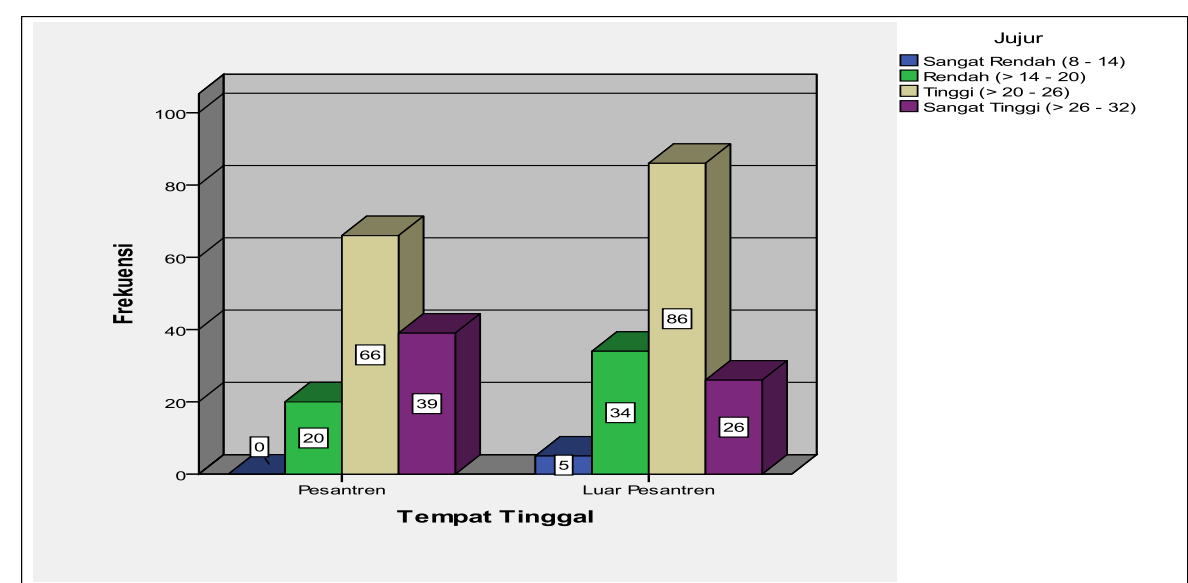

Figure 2. Differences The honest character value of the students living in pesantren and living outside pesantren

Table 3. The tolerance character value of the students living in pesantren and living outside pesantren

\begin{tabular}{|c|c|c|c|c|c|c|}
\hline & \multirow[b]{2}{*}{ Statistics } & \multicolumn{4}{|c|}{ tolerance } & \multirow[b]{2}{*}{ Total } \\
\hline & & Very low & Low & High & $\begin{array}{l}\text { Very } \\
\text { High }\end{array}$ & \\
\hline \multirow{3}{*}{$\begin{array}{l}\text { living in } \\
\text { pesantren }\end{array}$} & Count & 3 & 11 & 36 & 75 & 125 \\
\hline & $\begin{array}{l}\text { \% within Tempat } \\
\text { Tinggal }\end{array}$ & $2.4 \%$ & $8.8 \%$ & $28.8 \%$ & $60.0 \%$ & $100.0 \%$ \\
\hline & $\%$ of Total & $1.1 \%$ & $4.0 \%$ & $13.0 \%$ & $27.2 \%$ & $45.3^{\circ}$ \\
\hline
\end{tabular}


SOUTHEAST ASIAN JOURNAL OF ISLAMIC EDUCATION MANAGEMENT 2 (1) 2021

\begin{tabular}{|l|l|r|r|r|r|r|}
\hline $\begin{array}{l}\text { living outside } \\
\text { pesantren }\end{array}$ & Count & 2 & 17 & 67 & 65 & 151 \\
\cline { 2 - 6 } & $\begin{array}{l}\text { \% within Tempat } \\
\text { Tinggal }\end{array}$ & $1.3 \%$ & $11.3 \%$ & $44.4 \%$ & $43.0 \%$ & $100.0 \%$ \\
\cline { 2 - 6 } & \% of Total & $.7 \%$ & $6.2 \%$ & $24.3 \%$ & $23.6 \%$ & $54.7 \%$ \\
\hline
\end{tabular}

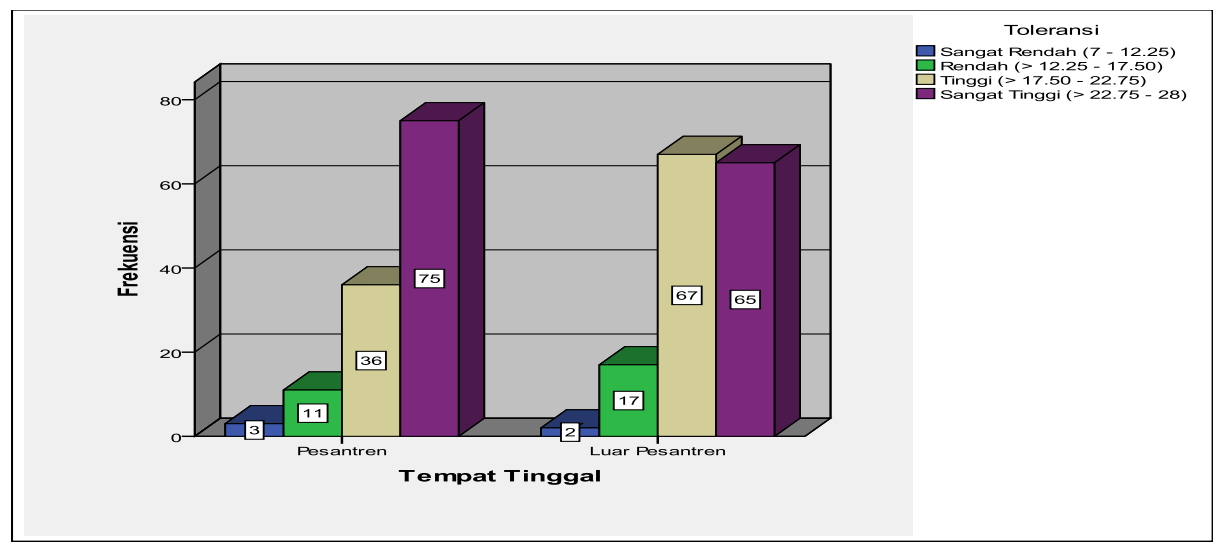

Figure 3. Differences The tolerance character value of the students living in pesantren and living outside pesantren

Table 4. The discipline character value of the students living in pesantren and living outside pesantren

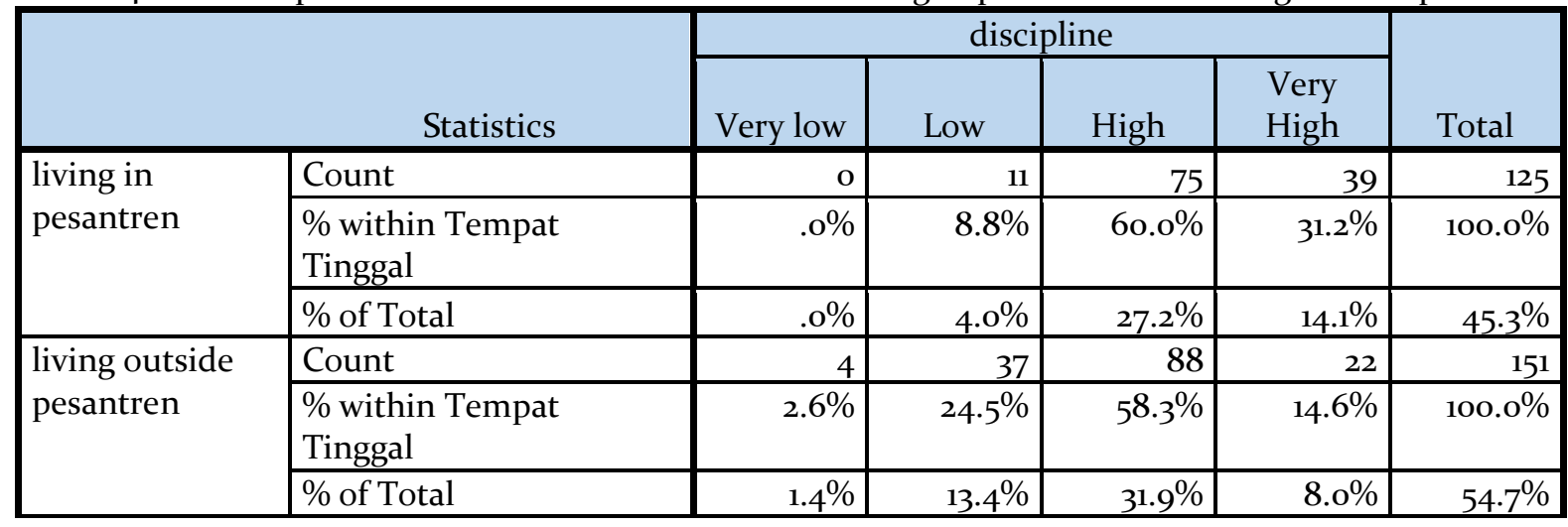

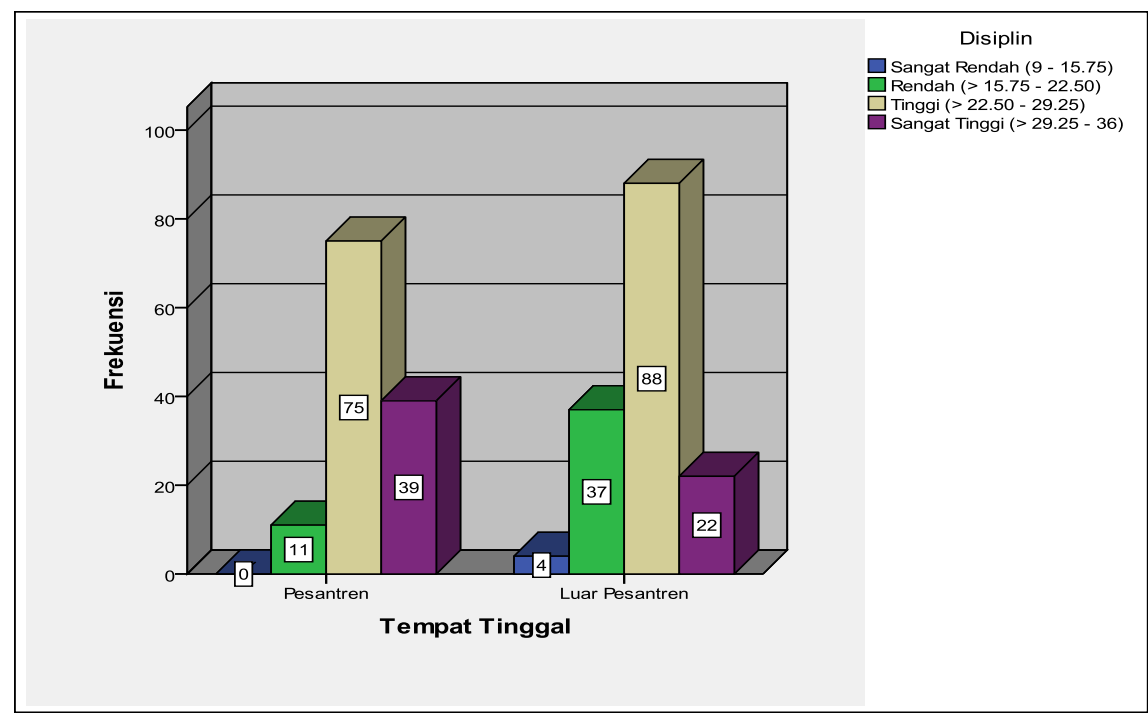

Figure 4. Differences The disipline character value of the students living in pesantren and living outside pesantren

Table 5. The independent character value of the students living in pesantren and living outside pesantren 


\begin{tabular}{|c|c|c|c|c|c|c|}
\hline & \multirow[b]{2}{*}{ Statistics } & \multicolumn{4}{|c|}{ independent } & \multirow[b]{2}{*}{ Total } \\
\hline & & Very low & Low & High & $\begin{array}{l}\text { Very } \\
\text { High }\end{array}$ & \\
\hline \multirow{3}{*}{$\begin{array}{l}\text { living in } \\
\text { pesantren }\end{array}$} & Count & 3 & 35 & 66 & 21 & 125 \\
\hline & $\begin{array}{l}\text { \% within Tempat } \\
\text { Tinggal }\end{array}$ & $2.4 \%$ & $28.0 \%$ & $52.8 \%$ & $16.8 \%$ & $100.0 \%$ \\
\hline & $\%$ of Total & $1.1 \%$ & $12.7 \%$ & $23.9 \%$ & $7.6 \%$ & $45.3 \%$ \\
\hline \multirow{3}{*}{$\begin{array}{l}\text { living outside } \\
\text { pesantren }\end{array}$} & \begin{tabular}{|l} 
Count \\
\end{tabular} & 9 & 78 & 54 & 10 & 151 \\
\hline & $\begin{array}{l}\text { \% within Tempat } \\
\text { Tinggal }\end{array}$ & $6.0 \%$ & $51.7 \%$ & $35.8 \%$ & $6.6 \%$ & $100.0 \%$ \\
\hline & $\%$ of Total & $3.3 \%$ & $28.3 \%$ & $19.6 \%$ & $3.6 \%$ & $54.7 \%$ \\
\hline
\end{tabular}

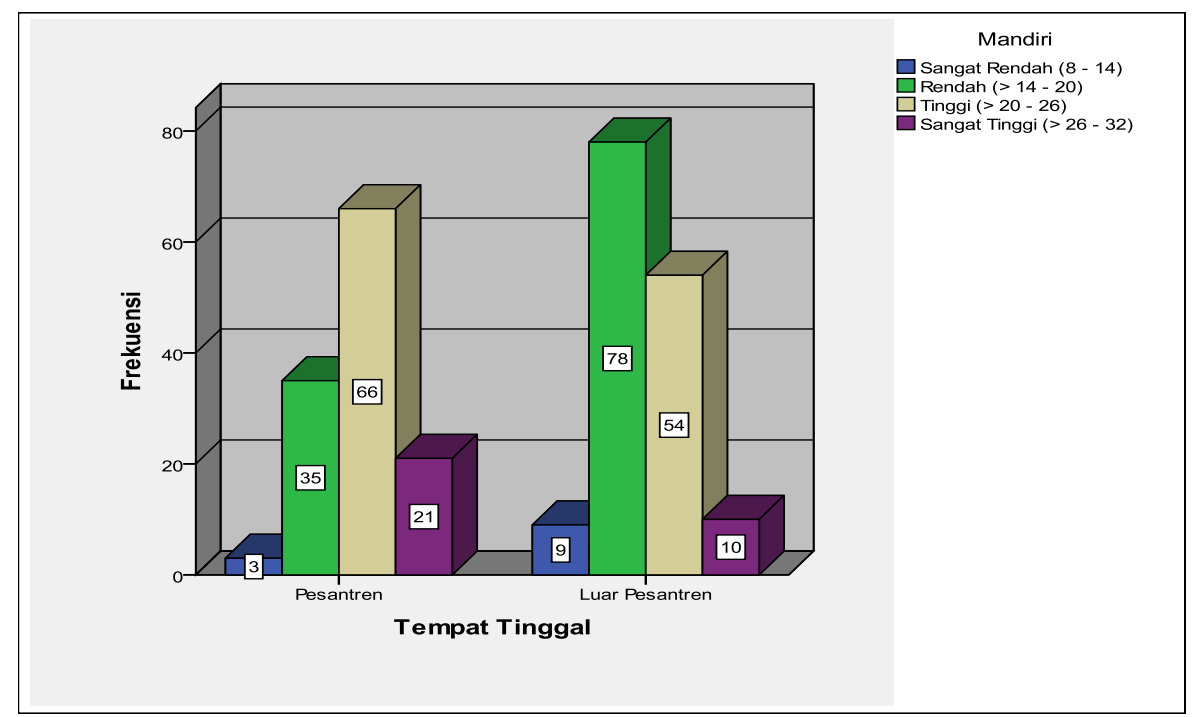

Figure 5. Differences The independet character value of the students living in pesantren and living outside pesantren

Table 6. The responsible character value of the students living in pesantren and living outside pesantren

\begin{tabular}{|c|c|c|c|c|c|c|}
\hline & \multirow[b]{2}{*}{ Statistics } & \multicolumn{4}{|c|}{ responsible } & \multirow[b]{2}{*}{ Total } \\
\hline & & Very low & Low & High & $\begin{array}{l}\text { Very } \\
\text { High }\end{array}$ & \\
\hline \multirow{3}{*}{$\begin{array}{l}\text { living in } \\
\text { pesantren }\end{array}$} & Count & 3 & 47 & 52 & 23 & 125 \\
\hline & $\begin{array}{l}\text { \% within Tempat } \\
\text { Tinggal } \\
\end{array}$ & $2.4 \%$ & $37.6 \%$ & $41.6 \%$ & $18.4 \%$ & $100.0 \%$ \\
\hline & $\%$ of Total & $1.1 \%$ & $17.0 \%$ & $18.8 \%$ & $8.3 \%$ & $45 \cdot 3 \%$ \\
\hline \multirow{3}{*}{$\begin{array}{l}\text { living outside } \\
\text { pesantren }\end{array}$} & Count & 5 & 73 & 50 & 23 & 151 \\
\hline & $\begin{array}{l}\text { \% within Tempat } \\
\text { Tinggal }\end{array}$ & $3.3 \%$ & $48.3 \%$ & $33.1 \%$ & $15.2 \%$ & $100.0 \%$ \\
\hline & $\%$ of Total & $1.8 \%$ & $26.4 \%$ & $18.1 \%$ & $8.3 \%$ & $54.7 \%$ \\
\hline
\end{tabular}




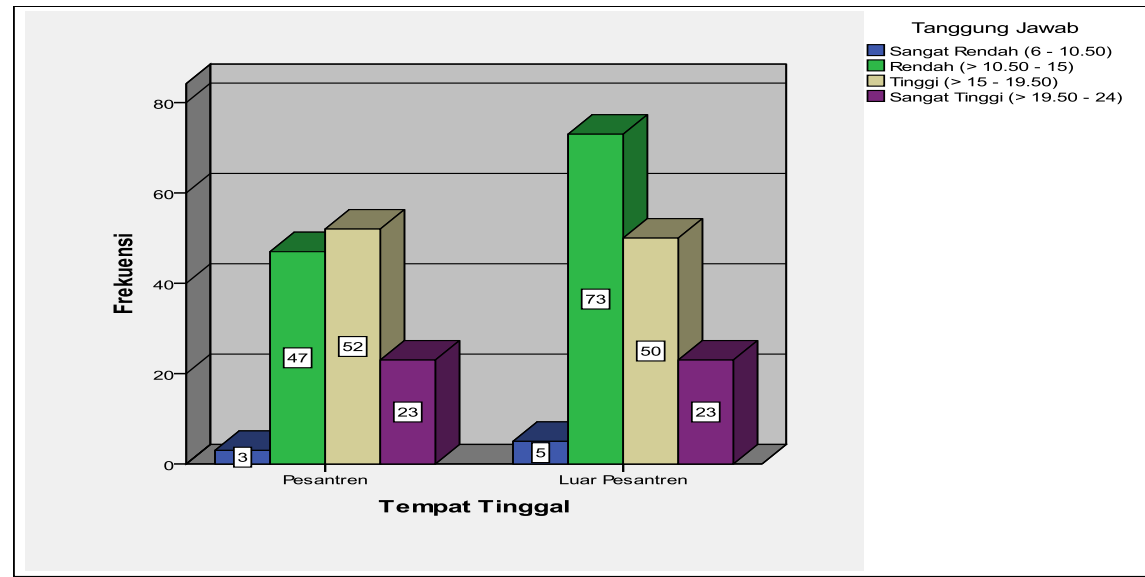

Figure 6. Differences The responsible character value of the students living in pesantren and living outside pesantren

\section{a. Normality test}

The results of the normality test with Kolmogorov-Smirnov are as follows:

Table 7. The results of the normality test

\begin{tabular}{|c|c|c|c|}
\hline Variabel & $\begin{array}{c}\text { Kolmogorov- } \\
\text { Smirnov }\end{array}$ & $\begin{array}{c}\text { Asymp. Sig. } \\
\text { (2-tailed) }\end{array}$ & Category \\
\hline student character & 0,893 & 0,402 & Normal \\
\hline
\end{tabular}

In the normality test the student character variables are known significance value (Asymp.Sig 2-tailed) of o,402. The value is more than the significance level of 5\% iso,402 > 0.05 then the value of these variables have been normally distributed.

b. Homogeneity Test

The results of the normality test with Levene Statistic are as follows:

Table 8 . The results of the homogeneity test

\begin{tabular}{|c|c|c|c|}
\hline Variabel & $\begin{array}{c}\text { Levene } \\
\text { Statistic }\end{array}$ & Signifikansi & Category \\
\hline student character & 2,683 & 0,103 & Homogen \\
\hline
\end{tabular}

In character variable of student is known significant value equal to 0,103 . This value is more than $5 \%$ significance level of $0,103>0.05$. From these results, it is known that both data have significance> 0.05 so that both data have the same or homogeneous group variance.

c. Hypothesis Test

Table 9. Results of t-Test of Learning Achievement between students living in Pesantren and outside Pesantren

\begin{tabular}{|c|c|c|c|c|c|}
\hline Date & t count & t table & Df & $\begin{array}{c}\text { Sig. (2- } \\
\text { tailed) }\end{array}$ & Category \\
\hline student character & 7.823 & 1,971 & 274 & 0,000 & Difference \\
\hline
\end{tabular}

The results are as follows. There are differences of character between students living in pesantren and students living outside pesantren in MTs. Al-Mahalli Bantul Yogyakarta, the 
acquisition of hypothesis test shows that the null hypothesis (Ho) is rejected and the alternative Hypothesis (Ha) accepted is $t$ arithmetic $>t$ table $(7,823>1,971)$ and the sig value. 2-tailed $(0.000<0.05)$.

Explanation of results: The characters of the students in the very low category both living in pesantren and outside the pesantren are the same, the character of the students in the low category who live outside pesantren more than those living in the pesantren, the characters of the high category students who live in pesantren and outside the pesantren, and the character of the students in very high category who live in pesantren more than outside the pesantren. Viewed from the average of both, the character of students living in pesantren is higher that has an average of 144,4 while the character of students who live outside the boarding school has an average of 133,4. Thus, it can be concluded that the character of students living in pesantren is higher than the characters of students living outside the pesantren. Meaning if students are in MTs. Al Mahalli Bantul Yogyakarta lives in pesantren, so the character of the students is better than the students who live outside the pesantren especially in social studies, and the character is the character that includes religious values, honesty, tolerance, discipline, independence, and responsibility.

\section{Conclusion}

There is a significant difference in the character of the students who live in Islamic boarding schools and outside pesantren on social studies learning at MTs. Al-Mahalli Bantul Yogyakarta. There are differences in the character of these students by environmental factors of residence. This shows that with living in the pesantren and outside pesantren, then the character of the students who are formed is also different, character students in pesantren are higher outside of pesantren.

\section{References}

Andrianto, T. T., “Mengembangkan Karakter Sukses Anak di Era Cyber,” Ar-Ruzz Media, 2011.

Damon, William, Bringing in a New Era in Character Education. California: Hoover Institution Press. 2002

Dhofier, Z., “Tradisi Pesantren Studi Tentang Pandangan Hidup Kiai,” LP3ES, 2011.

Kamaruddin, S. A., “Character Education and Students Social Behavior”. Journal of Education and Learning 6 (4), 223-230 (2012).

Lickona, T.,"Educating for character: How our school can teach respect and responsibility," Bantam books, 1991.

Munawaroh, S. (2013). Perilaku disiplin dan kejujuran generasi muda di Daerah Istimewa Yogyakarta. Yogyakarta: Balai Pelestarian Nilai Budaya.

Restianingsih, P., “Karakter Siswa yang Tinggal di Pesantren (Mukim) dan di Rumah (Laju) pada Proses Pembelajaran IPS di SMP Diponegoro Depok, Kabupaten Sleman," Pascasarjana UNY, (2016). 
Rohmaniyah, I., \& Woodward, M., "Wahhabism, Identity and Secular Ritual: Graduation at an Indonesian High School”. Jurnal Al-Jami'ah, 50 (1), (2012).

Sugiyono., "Metode Penelitian Kuantitatif Kualitatif dan RED," Alfabeta, 2015. 